\title{
MENINGKATKAN PEMAHAMAN ILMU TAJWID MENGGUNAKAN METODE HALAQAH DI MIS ASSASUL ISLAM BOGOR
}

\author{
Siti Fatimah, Kamilah Rahmawati, Siti Sabilah Salmah \\ fatimahntdgs@gmail.com \\ Mahasiswa Fakultas Agama Islam Universitas Ibn Khaldun
}

\begin{abstract}
ABSTRAK
Dari sejak usia dini, dibangku sekolah atau TPA kita sudah diperkenalkan dan diajarkan macam-macam huruf hija'iyah dan disertai dengan pembelajaran ilmu tajwid, sehingga setelah remaja kelak kita sudah mampu membaca Al-Qur'an dengan baik dan benar. Namun kenyataannya masih banyak anak-anak dan orang tua yang sudah hafal huruf-huruf hija'iyah namun belum tentu benar dalam membaca Al-Qur'annya, karena mereka tidak memahami cara membaca Al-Qur'an sesuai kaidah ilmu tajwid. Dari permasalahan yang kami lihat di lingkungan sekitar terutama untuk anak-anak di tingkat Sekolah Dasar, maka dari itu kami ingin meningkatkan pemahaman mengenai ilmu tajwid dan bukan hanya sekedar paham saja namun diaplikasikan juga dalam bacaan Al-Qur'annya. Tujuan Khusus Penelitian Untuk mengetahui model pembelajaran halaqoh dapat meningkatkan pemahaman siswa terhadap ilmu tajwid dan Untuk mengetahui model halaqoh yang sesuai untuk meningkatkan pemahaman pembelajaran ilmu tajwid
\end{abstract}

Kata Kunci: Ilmu Tajwid, Metode Halaqah, Membaca Al-Qur'an.

\section{PENDAHULUAN}

\section{Latar Belakang}

Membaca Al-Qur'an merupakan hal yang harus dilakukan oleh seorang umat muslim, baik di Indonesia maupun dinegara lain. Hukum melakukannya adalah fardhu 'ain. Dalam membaca AlQur'an tentu kita harus memperhatikan bagaimana cara membaca Al-Qur'an yang baik dan benar sesuai dengan bacaan Rasulullah. Hal pertama yang harus kita lakukan agar mampu membaca Al-Qur'an dengan baik dan benar setelah kita mengetahui huruf-huruf hija'iyah adalah dengan mempelajari dan memahami ilmu tajwid. Ilmu tajwid merupakan ilmu yang mempelajari tata cara membaca Al-Qur'an dengan baik dan benar sesuai dengan kaidah Al-Qur'an.
Dari sejak usia dini, dibangku sekolah atau TPA kita sudah diperkenalkan dan diajarkan macam-macam huruf hija'iyah dan disertai dengan pembelajaran ilmu tajwid, sehingga setelah remaja kelak kita sudah mampu membaca Al-Qur'an dengan baik dan benar. Namun kenyataannya masih banyak anak-anak dan orang tua yang sudah hafal huruf-huruf hija'iyah namun belum tentu benar dalam membaca Al-Qur'annya, karena mereka tidak memahami cara membaca Al-Qur'an sesuai kaidah ilmu tajwid.

Dari permasalahan yang kami lihat di lingkungan sekitar terutama untuk anakanak di tingkat Sekolah Dasar, maka dari itu kami ingin meningkatkan pemahaman mengenai ilmu tajwid dan bukan hanya 
sekedar paham saja namun diaplikasikan juga dalam bacaan Al-Qur'annya nanti. Untuk mempermudah pemahaman anakanak pada saat membaca Al-Qur'an, kami menggunakan metode halaqoh Qur'an. Metode halaqoh Qur'an ini kami padukan dengan metode talaqi agar lebih efektif dalam melihat sejauh mana kesalahan siswa-siswi dalam membaca Al-Qur'an. Sehingga guru atau murabbinya nanti dapat mengetahui siswa mana yang sudah ataupun belum lancar membaca sesuai dengan kaidah ilmu tajwid.

\section{Rumusan Masalah}

Berdasarkan penjelasan yang telah diuraikan pada latar belakang di atas, maka penulis merumuskan permasalahan sebagai berikut:

1. Apakah model pembelajaran halaqoh dapat meningkatkan pemahaman siswa terhadap ilmu tajwid?

2. Bagaimana metode pembelajaran halaqoh yang sesuai untuk meningkatkan pemahaman pembelajaran ilmu tajwid serta diaplikasikan dalam membaca alqur'an?

\section{Tujuan Khusus Penelitian}

Berdasarkan rumusan masalah diatas, maka penelitian ini bertujuan khusus untuk:

1. Untuk mengetahui model pembelajaran halaqoh dapat meningkatkan pemahaman siswa terhadap ilmu tajwid.

2. Untuk mengetahui model halaqoh yang sesuai untuk meningkatkan pemahaman pembelajaran ilmu tajwid

\section{Urgensi Penelitian}

Keutamaan dalam penelitian ini adalah diharapkan siswa-siswi di MIS Assasul Islam dapat meningkatkan pemahaman mereka dalam pembelajaran ilmu tajwid serta mengaplikasikannya dalam bacaan Al-Qur'an dengan bacaan yang benar sesuai dengan kaidah ilmu tajwid.

\section{Temuan yang Ditargetkan}

Temuan dalam penelitian ini yaitu model pembelajaran halaqoh yang dapat digunakan dalam pembekajaran ilmu tajwid, dengan pembentukan 8-15 orang dalam halaqoh Al-Qur'an tersebut kemudian guru melakukan metode talaqqi yang berguna untuk mengetahui letak kesalahan dalam bacaan Al-Qur'an.

\section{Kontribusi terhadap Ilmu Pengetahuan Sosial dan Humaniora}

Kontribusi dari penelitian ini untuk ilmu pengetahuan dan humaniora yaitu untuk memecahkan permasalahn sosialhumaniora terkait dengan konsep dalam tata cara beribadah/membaca Al-Qur'an dengan baik dan benar agar kaitannya dengan hubungan manusia pundapat lancar.

\section{Luaran}

1. Diperoleh model pembelajaran halaqoh menggunakan metode talaqqi dalam meningkatkan pemahaman ilmu tajwid dan cara membaca Al-Qur'an sesuai kaidah ilmu tajwid.

2. Artikel atau paper pada jurnal nasional "Jurnal Penelitian Pendidikan"

\section{Manfaat Penelitian}

1. Bagi peneliti Hasil dari penelitian ini beguna untuk menambah pengetahuan dan keterampilan peneliti mengenai model pembelajaran halaqoh pada pembelajaran Ilmu Tajwid;

2. Bagi guru Hasil penelitian ini dapat memberikan wawasan dan keterampilan 
untuk mengaplikasikan model pembelajaran halaqoh pada pembelajaran Ilmu Tajwid di sekolah dasar;

3. Bagi siswa Hasil dari penelitian ini berguna untuk mengantarkan para

\section{TINJAUAN PUSTAKA}

Tinjauan pustaka ini dimaksudkan untuk mengemukakan teori-teori yang relevan dengan masalah yang akan diteliti, dan akan dijadikan dasar pemikiran dalam penelitian ini. Berikut merupakan tinjauan pustaka dari masing-masing variabel dan hal yang terkait dengannya.

\section{Metode Halaqah Qur'an}

Menurut Munawwir, halaqah secara bahasa artinya adalah kalung, lingkaran, atau kumpulan orang yang duduk berbentuk lingkaran (Munawwir, 1997: 290). Sedangkan menurut Abudin Nata dalam bukunya pendidikan model halaqah merupakan pendidikan yang dilaksanakan dengan cara seorang guru duduk menyampaikan ilmu dan murid-murid duduk mengelilinginya dalam bentuk lingkaran (Abudin Nata, 2004: 35).

\section{Pembelajaran Ilmu Tajwid}

Secara etimologi, tajwid berarti memperbaiki (الـ ثُد ين ) Secara terminologi mengeluarkan setiap huruf dari tempat keluarnya serta memberikan haq dan mustaha-nya. Memberikan haq dan mustahaq setiap huruf, baik makhraj maupun huruf (Hartanto Suryono, 2016: 17). Ilmu tajwid yaitu ilmu yang dipergunakan untuk mengetahui tempat keluarnya huruf (makhraj), dan sifatsifatnya serta bacaan-bacaannya (Ahmad Soenarto, 1988: 6). Hukum mempelajari peserta didik di tingkat sekolah dasar untuk meningkatkan pemahaman tentang ilmu tajwid baik dalam pemahaman teori maupun cara membacanya.

ilmu tajwid secara teori adalah fardhu kifayah, sedangkan hukum membaca $\mathrm{Al}$ Qur'an dengan benar adalah fardhu 'ain (Ahmad Muzzammil, 2006: 3).

\section{Perbedaan Penelitian yang Dilaksanakan dengan Penelitian-penelitian Sebelumnya}

Beberapa penelitian yang dijadikan sebagai tinjauan penelitian ini adalah sebagai berikut: Baharuddin (UIN Alauddin Makassar, 2012) dalam tesisnya yang berjudul "Metode Pembelajaran Ilmu Tajwid Dalam Meningkatkan Kemampuan Membaca Al-Qur'an Santri Pondok Pesantren Tahfizh Al-Qur'an Al-Imam 'Ashim Makassar" menyimpulkan bahwa metode pembelajaran ilmu tajwid yang digunakan ditempat penelitian ini adalah metode jibril. Zulfahmi (Universitas Muhamadiyah Surakarta, 2013) dalam skripsinya yang berjudul "Pendidikan Model Halaqah Dalam Meningkatkan Pendidikan Agama Islam (Studi Pendidikan Nonformal Di Desa Pilang, Kec. Masaran, Kab. Sragen" menyimpulkan bahwa pendidikan model halaqoh yang ada di desa Pilang dirintis dari kecil sehingga mengalami perkembangan yang sangat pesat. Dalam pelaksanaannya model halaqoh ini dibagi kedalam kelompok kecil yang terdiri dari 8 sampai 15 orang dibawah bimbingan seorang guru. 


\section{METODE PENELITIAN}

\section{Tahapan Penelitian}

Penelitian ini menggunakan metode penelitian tindakan kelas (classroom action research). Menurut Prof. Dr. Suryana M.Si. penelitian tindakan (action research) merupakan salah satu pendekatan baru dalam memecahkan masalah atau mengembangkan keterampilanketerampilan baru di dunia praktis yang dilakukan secara reflektif (Suryana, 2010: 43). Kemmis dan McTaggart menjelaskan bahwa riset tindakan sebagi bentuk refleksi diri kolektif yang dilakukan oleh para partisipan dalam situasi sosial dengan tujuan memajukan produktivitas, rasionalitas, keadilan pada persoalan sosial, atau praktik pendidikan. Guru, kepala sekolah, orang tua, siswa, dan masyarakat adalah partisipan (Suparno, 2008: 6).

Penelitian dilakukan pada siswa kelas V dan VI di MIS Assasul Islam Kota Bogor dengan menggunakan materi ilmu tajwid berupa makharijul huruf dan cara membacanya, ghunnah, bacaan mad (panjang dan pendek), dan tanda baca waqof. Alur tindakan kelas (classroom action research) yang kami gunakan dapat dilihat pada halaman lampiran, dengan menggunakan 3 siklus dalam proses penelitian. Design penelitian ini menggunakan empat tahapan, penyusunan rencana (planning), tindakan (action), observasi (observating), dan refleksi. Keempat tahapan ini membentuk satu siklus, yaitu satu putaran kegiatan yang berurutan. Apabila pada tahap akhir yaitu refleksi penelitian belum tercapai maka akan kembali lagi ke tahap awal yaitu tahap perencaan, begitu seterusnya tahapan yang akan dilakukan oleh peneliti sehingga tujuan dari penelitian tersebut tercapai.

\section{Indikator Capaian Yang Terukur Pada Tiap Tahapan}

Indikator capaian dalam penelitian ini yaitu:

1. Pada tahap melakukan tindakan, akan diperoleh model pembelajaran halaqoh yang sesuai dengan kebutuhan pembelajaran ilmu tajwid. Dalam tahapan tindakan ini siswa-siswi lebih dijelaskan mengenai materi-materi ilmu tajwid secara lebih rinci dalam pembentukkan halaqoh, karena dalam pembentukkan halaqoh ini hanya terdiri dari beberapa siswa saja sehingga guru lebih dapat memantau sejauh mana kesalahan bacaan al-qur'an dan pemahaman mereka terhadap ilmu tajwid.

2. Akan menghasilkan peserta didik yang mahir dalam membaca Al-Qur'an sesuai kaidah ilmu tajwid.

\section{Teknik Pengumpulan Data}

Teknik pengumpulan data pada penelitian ini dilakukan dengan tes, observasi, dan catatan

\section{Analisis Data}

Pada penelitian ini terdapat dua kelompok data yang akan dianalisis, yaitu dari hasil observasi yang dilakukan pada saat prose pembelajaran berlangsung dengan melihat keaktifan siswa dalam proses pembelajaran, dan data dari hasil pre-test, post test 1 , dan post test 2 . Untuk melihat keaktifan siswa dalam proses pembelajaran, masing-masing aktivitas siswa akan di presentasikan dengan rumus:

$$
P=\frac{F}{N} \times 100 \%
$$

Keterangan: $\mathrm{P}=$ Angka presentase aktivitas, $\mathrm{F}=$ Frekuensi aktivitas siswa, $\mathrm{N}$ = jumlah siswa 
Tabel 1. Presentase Aktivitas Belajar Siswa

\begin{tabular}{|c|c|}
\hline Persentase Aktivitas Siswa & Kategori \\
\hline $0 \%<\mathrm{P}<20 \%$ & Kurang sekali \\
\hline $20 \%<\mathrm{P}<40 \%$ & Kurang \\
\hline $40 \%<\mathrm{P}<60 \%$ & Cukup \\
\hline $60 \%<\mathrm{P}<80 \%$ & Baik \\
\hline $805 \%<\mathrm{P}<100 \%$ & Baik sekali \\
\hline
\end{tabular}

\section{BIAYA DAN JADWAL KEGIATAN}

Anggara Biaya

Tabel 2 Ringkasan Anggaran Biaya PKM-P

\begin{tabular}{|c|c|c|}
\hline No. & Jenis Pengeluaran & Biaya (Rp.) \\
\hline 1. & $\begin{array}{c}\text { Peralatan penunjang } \\
\text { Modul Buku Tajwid, Media Pembelajaran, dan } \\
\text { sewa printer }\end{array}$ & Rp. 1.595 .000 \\
\hline 2. & $\begin{array}{c}\text { Bahan habis pakai } \\
\text { Tinta printer, kertas A4, fotocopy, ATK, } \\
\text { internet data }\end{array}$ & Rp. 780.000 \\
\hline 3. & $\begin{array}{l}\text { Perjalanan observasi sekolah dan lainnya } \\
\text { (selama } 5 \text { bulan), dan penelitian }\end{array}$ & Rp. 3.000 .000 \\
\hline 4. & $\begin{array}{c}\text { Lain-lain } \\
\text { Penggandaan laporan, seminar hasil PKM, dan } \\
\text { dokumentasi }\end{array}$ & Rp. 675.000 \\
\hline & Jumlah & Rp. 6.050 .000 \\
\hline
\end{tabular}

Jadwal Kegiatan

\begin{tabular}{|c|c|c|c|c|c|c|}
\hline No. & Kegiatan & $\begin{array}{c}\text { Bulan } \\
\text { ke-1 }\end{array}$ & $\begin{array}{c}\text { Bulan } \\
\text { Ke-2 }\end{array}$ & $\begin{array}{l}\text { Bulan } \\
\text { Ke-3 }\end{array}$ & $\begin{array}{c}\text { Bulan } \\
\text { Ke-4 }\end{array}$ & $\begin{array}{c}\text { Bulan } \\
\text { Ke-5 }\end{array}$ \\
\hline 1. & Persiapan Penelitian & & & & & \\
\hline 2. & $\begin{array}{l}\text { Pembuatan Instrumen } \\
\text { (penyusunan rencana) }\end{array}$ & & & & & \\
\hline 3. & $\begin{array}{l}\text { Pelaksanaan tindakan } \\
\text { (siklus } 1 \text { s.d siklus 3) }\end{array}$ & & & & & \\
\hline 4. & Pengumpulan data & & & & & \\
\hline 5. & Analisis data & & & & & \\
\hline 6. & Pembuatan Laporan & & & & & \\
\hline
\end{tabular}




\section{DAFTAR PUSTAKA}

Munawwir, Ahmad. Al-Munawwir (Kamus Arab - Indonesia), Surabaya: Pustaka Progressif. 1997.

Muzzammil MF, Al Hafizh, Ahmad. Panduan Tahsin Tliawah Kajian Ilmu Tajwid Semester 1. Tangerang: Ma'had Al-Qur'an Nurul Hikmah: 2006.

Nata, Abudin. Sejarah Pendidikan Islam

(Pada Periode Klasik dan Pertengahan), Jakarta: PT. Raja Grafindo Persada. 2004.

Saryono, Hartanto. Tajwid Al-Qur'an Riwayat Hafsh dari 'Ashim, Depok: Rumah Tajwid. 2016. 